УдК 634.83:631.537^626.81/.85.003.12

DOI: $10.31395 / 2310-0478-2021-2-84-90$

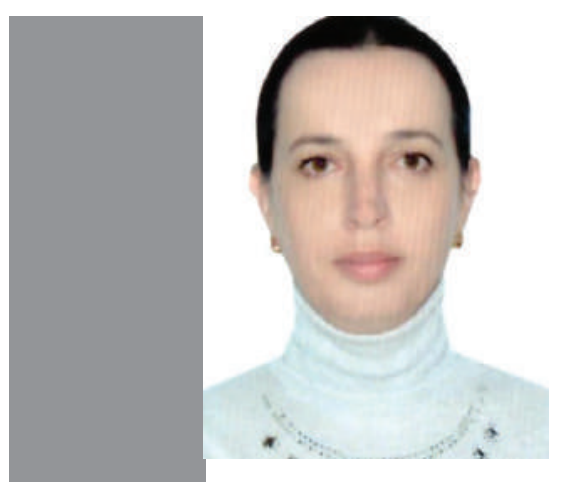

\title{
Н.М. Зеленянська
}

доктор сільськогосподарських наук, старший науковий співробітник Національного наукового центру

«Інститут виноградарства і виноробства імені В.Є. Таїрова», м.Одеса, Україна

E-mail: natalyanikolaevna2019@ukr.net

B. В. Борун

кандидат сільськогосподарських наук, старший науковий співробітник Національного наукового центру «Інститут виноградарства і виноробства імені В.Є. Таїрова», м.Одеса, Україна E-mail: borunv@ukr.net

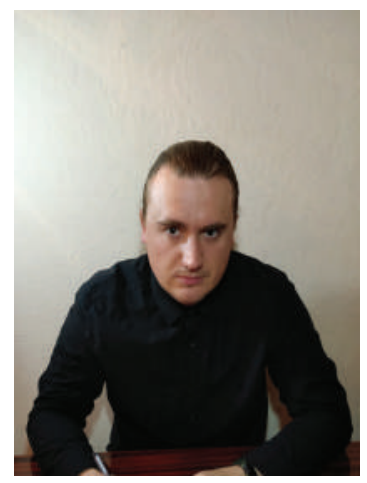

\section{ЕКОНОМІЧНА ОЦІНКА РЕЖИМІВ КРАПЛИННОГО ЗРОШЕННЯ ВИНОГРАДНОЇ ШКІЛКИ В УМОВАХ ПІВДНЯ УКРАЇНИ}

\begin{abstract}
У статті наведено результати досліджень щодо визначення економічної ефективності різних режимів краплинного зрошення на виноградній шкілці. Встановлено, що економічний ефект досягався за рахунок збільшення виходу стандартних саджанців із шкілки, економії поливної води, електроенергії, дотримання раціональних схем садіння щеп у шкілці. За результатами даної роботи виробництву запропоновано оптимальні режими краплинного зрошення виноградної шкілки, які сприяють підвищенню виходу стандартних саджанців із шкілки до 55-60\%. Найбільший рівень рентабельності був у варіантах, де щепи висаджували в шкілці стрічкою у два рядки з монтажем однієї краплинної стрічки, а вологість Ґрунту підтримували на рівні 100-90\%, 100-80\% НВ та 100-90-80\% НВ. У цих варіантах він дорівнював 346,7\%, 334,4\% та 340,2\% при 305,6\% у контролі 1 (висаджування щеп винограду стрічкою у два рядки). Вартість використаних енергетичних ресурсів та їх виробничі об'єми зменшувались, у середньому, на 72,0-78,0\%.

Ключові слова: щеплені саджанці винограду, краплинне зрошення, рівні передполивної вологості ґрунту, економічна ефективність.
\end{abstract}

Zelenyanska N. M.,

Doctor of Agricultural Sciences, Senior Research Scientist,

National Scientific Centre «V.Ye. Tairov Institute of Viticulture and Winemaking», Odesa, Ukraine

Borun V. V.

Phd of Agricultural Sciences, Senior Research Scientist,

National Scientific Centre «V.Ye. Tairov Institute of Viticulture and Winemaking», Odesa, Ukraine

\section{ECONOMIC ASSESSMENT OF DRIP IRRIGATION REGIMES OF A GRAPE NURSERY IN THE CONDITIONS OF THE SOUTH OF UKRAINE}

The article presents the results of research to determine the economic efficiency of different modes of drip irrigation in the grape nursery. It has been established that the economic effect is achieved by increasing the yield of standard seedlings from the nursery, saving irrigation water, electricity, observing rational schemes of planting grafts in the nursery. The purpose of the research is to conduct an economic assessment of different modes of drip irrigation of grape nursery, to determine the most effective for implementation in production. Methods. Field, laboratory, and computational methods were used in the work. Results. According to the scheme of researches, grape grafts were planted in a nursery by a tape with one and two rows, in each tape mounted one or two drip tapes. Pre-irrigation soil moisture at the grape nursery was maintained at different levels - 100$90 \%$ of the lowest moisture capacity (LMC), 100-80\% LMC, 100-90-80\% LMC, and 100-80-70\% LMC. It is shown that the highest level of profitability in the cultivation of grafted grape seedlings was in the variants where the grafts were planted in the nursery with a tape in two rows and with the mounted of one drop tape, and LPSM supported 100-90\% LMC and 100-90-80\% LMC - 346, 7\% and 340.2\%. They were somewhat inferior in this respect to the options where the grafts were also planted in the nursery with a tape in two rows, but for their watering mounted two drip tapes $-333.5 \%$ and $337.0 \%$. When planting grape grafts in the nursery with tape in one row and with the maintenance of LPSM 100-90\% LMC, 100-80\% LMC, 100-90-80\% LMC the level of profitability of the technology of growing grafted grape seedlings was almost at the same level - 254.1-259.2\%. Variants of the experiment with the maintenance of LPSM 100-80-70\% LMC, regardless of the schemes of planting grafts in the nursery, were characterized by the lowest level of profitability - 133.8\%. He was second only to control 2 with a level of profitability $-42.7 \%$. Conclusions. The economic effect of drip irrigation on the grape nursery was achieved by increasing the yield of standard seedlings from the nursery, saving irrigation water, electricity, and compliance with rational schemes of planting grafts in the nursery. The highest level of profitability of growing grafted grape seedlings was in the variants where the 
grafts were planted in the nursery with a tape in two rows with the mounted of one drop tape, and soil moisture was maintained at $100-90 \%, 100-80 \% \mathrm{HB}$ and $100-90-80 \% \mathrm{HB}$. In these variants, it was equal to $346.7 \%, 334.4 \%$ and $340.2 \%$ with $305.6 \%$ in control 1. The cost of used energy resources and their production volumes decreased, on average, by $72.0-78,0 \%$. These modes of drip irrigation of grape seedlings are recommended for use in nurseries and nursery practitioners.

Keywords: grafted grape seedlings, drip irrigation, levels of pre-irrigation soil moisture, economic efficiency.

Постановка проблеми. Сільське господарство України в певній мірі формує продовольчу, економічну, екологічну, енергетичну безпеку, забезпечує розвиток технологічно пов'язаних галузей національної економіки та створює соціально-економічні умови сільського розвитку. Увага до проблеми підвищення економічної ефективності сільськогосподарського виробництва в цілому та вирощування щеплених виноградних саджанців зокрема зумовлена потребою вирішення питання зростання дохідності підприємств, підвищення конкурентоспроможності продукції на внутрішньому та світовому ринках $[1,2]$. Такі перетворення можливо здійснити на основі застосування прогресивних, економічно доцільних технологій ефективного водопостачання та рівня використання потенціалу меліорованих земель. У зв'язку з цим, виникає потреба у більш точному диференційованому плануванні режимів зрошення та норм водоспоживання сільськогосподарських культур з урахуванням комплексу природних, технічних, технологічних, соціально-економічних та господарських умов на конкретних об'єктах [3].

У виноградному розсадництві цей напрям реалізується на основі впровадження технологій краплинного зрошення. Удосконалення, розробка технологій, їх впровадження у виробництво, окрім технологічної доцільності, повинно бути економічно ефективним, сприяти збільшенню виходу готової продукції, зниженню показників її собівартості при високій якості та збільшенні рівня рентабельності виробництва.

При виробництві сільськогосподарської продукції використовуються переважно такі види енергетичних ресурсів - дизельне пальне, бензин, газ, електроенергія та вода. Система економії енергоресурсів у сільському господарстві передбачає оптимізацію їх витрат на виробництво продукції без зниження ії якості та номенклатури. Економічний ефект у промисловому виноградному розсадництві досягається, в основному, шляхом підвищення виходу щеплених саджанців із шкілки, зменшення витрат матеріальних ресурсів та збільшення продуктивності праці. У наших дослідженнях, після застосування краплинного зрошення на виноградній шкілці, він досягався за рахунок збільшення виходу стандартних саджанців із шкілки, економії поливної води та електроенергії, дотримання раціональних схем садіння щеп у шкілці.

Аналіз останніх досліджень і публікацій. Для ефективного впровадження технології краплинного зрошення на виноградній шкілці в першу чергу необхідно розробити режими поливу, які забезпечать зменшення використання поливної води, енергетичних ресурсів і автоматизацію процесу. Далі необхідно визначити способи діагностики оптимальних строків і поливних норм.

Слід зазначити, що наукових робіт, пов'язаних із застосуванням краплинного зрошення у виноградному розсадництві, дуже мало. Окремі роботи в цьому напрямку, проводили болгарські вчені Цветанов Е. та Куманов К. в інституті виноградарства і виноробства (м. Плевен, Болгарія). Дослідження проводили на саджанцях винограду сорту Міскет Кайлишкі, щеплених на підщепу Берландіері x Ріпарія CO4, які вирощували в шкілці при краплинному зрошенні у поєднанні з дощуванням. На основі проведених досліджень Цветанов Е., Куманов К. встановили, що режим краплинного зрошення виноградної шкілки повинен формуватися на основі глибини розташування кореневої зони щеплених саджанців винограду протягом вегетації, а це приблизно 60-80 см. Глибина кореневої зони щеплених саджанців не $\epsilon$ постійною, вона змінюється протягом вегетації, поступово збільшуючись. На початку вегетації, коли щепи не мають кореневої системи, зволоження ґрунту на глибину
60-80 см є недоцільним і призводить лише до надмірних витрат поливної води та робочої сили [4].

у країнах ближнього зарубіжжя роботу у цьому напрямку, проводили А. В. Кириченко, А. В. Дутова і Н. В. Бєлік. Ґрунтоутворюючі породи на дослідних ділянках були представлені темно-бурими карбонатами і карбонатно-лісовидними суглинками. Основною метою їх роботи було визначення вологості ґрунту і призначення строків поливу виноградної шкілки тензіометричним методом. Показано, що за оперативністю визначення строків поливу цьому методу слід віддавати перевагу. Найбільш економічно ефективним був режим зрошення з підтримкою вологості шару ґрунту 0-70 см на рівні 80-100\% НВ з поливною нормою 320 м³/га. Такий режим зрошення дозволяв отримувати рентабельність в 210\% за найменшої собівартості одного саджанця [5].

М. С. Григоров, Н. В. Курапіна, Д. Е. Гусєв, I. П. Кружилін проводили дослідження в зоні різко континентального клімату з каштановими ґрунтами. Особливістю цих ґрунтів є їх висока комплексність, обумовлена поширенням великої кількості солонців. Гранулометричний склад ґрунтів змінювався від глинистого до супіщаного. У даних умовах було встановлено, що краплинне зрошення, у порівнянні з дощуванням, забезпечувало економію води до 10 разів. Оптимальні РПВҐ (рівень передполивної вологості ґрунту) для культивування кореневласних саджанців у шарі ґрунту 0,0-0,6 м необхідно підтримувати на рівні $85-90 \%$ НВ у фазу активного росту з наступним зниженням ії до 70-75\% НВ. Рівень рентабельності в цьому варіанті становив 126,6\% [6].

Проведений аналіз літературних джерел показав що наукових праць стосовно застосування краплинного зрошення для поливу виноградної шкілки дуже мало, а наукові праці по розрахунку економічної ефективності його застосування загалом відсутні. Тому вирішення цих питань сьогодні є надзвичайно актуальним.

Мета статті. Провести економічну оцінку різних режимів краплинного зрошення виноградної шкілки, визначити найбільш ефективні для застосування у виробництві.

Методика дослідження. Робота виконувалась протягом 2015-2017 рр. у відділі розсадництва і розмноження винограду ННЦ «ІВіВ імені В. Є. Таїрова», виробничі випробування проводили протягом 2018-2019 рр. у Державному підприємстві «Дослідне господарство «Таїровське» (ДП «ДГ «Таїровське»). Розрахунки основних економічних показників проводили на основ технологічних карт, прийнятих у ННЦ «ІВіВ імені В. $Є$. Таїрова» та з урахуванням витрат на виготовлення щеп у ДП «ДГ «Таїровське» при вирощуванні щеплених саджанців винограду технічного сорту винограду - Каберне Совіньйон, виготовлених на підщепі Р х P 101-14.

Ширина міжрядь у шкілці становила 1,4 м, відстань між щепами у рядку 7,0-8,5 см (залежно від схеми садіння щеп), відстань між рядками щеп у стрічці 15 см, глибина садіння щеп - 20-25 см.

Для монтажу системи краплинного зрошення застосовували краплинні стрічки з товщиною стінки 0,15 мм, діаметром - 16 мм з інтегрованими водовипусками через кожні 10 см і витратою води 1,0 дм³/год. Їх розташовували на поверхні ґрунтових «горбиків» під чорною поліетиленовою плівкою товщиною 60 мкм. Досліди закладали методом рендомізованого розміщення варіантів у трьохкратній повторності, у кожному варіанті було по 400 облікових щеп.

У схему досліджень було включено три досліди, які відрізнялися схемою висаджування щеп у шкілці та монтажем краплинних стрічок.

Дослід 1 - Висаджування щеп винограду в шкілці стрічкою у два рядки з монтажем двох стрічок краплин- 


\section{ного зрошення.}

Дослід 2 - Висаджування щеп винограду в шкілці стрічкою у два рядки з монтажем однієї стрічки краплинного зрошення.

Дослід 3 - Висаджування щеп винограду в шкілці стрічкою в один рядок з монтажем однієї стрічки краплинного зрошення.

у кожному досліді було по 4 варіанти, в яких підтримували різні рівні РПВҐ.

Варіанти 1.1, 2.1, 3.1 - РПВґ 100-90\% НВ;

Варіанти 1.2, 2.2, 3.2 - РПВґ 100-80\% НВ;

Варіанти 1.3, 2.3, 3.3 - РПВҐ 100-90\% НВ у період укорінення щеп, надалі 100-80\% НВ (100-90-80\% НВ);

Варіанти 1.4, 2.4, 3.4 - РПВ 100-80\% НВ у період укорінення щеп, надалі 100-70\% НВ (100-80-70\% НВ).

Контрольними були варіанти, де для поливу щеп винограду використовували краплинне зрошення з різними зрошуваними нормами. Контроль 1 - зрошувана норма

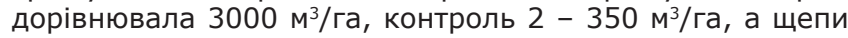
висаджували в шкілці стрічкою в один (К 1.1, 2.1) та два
(К 1.2, 2.2) рядки.

При садінні щеп винограду стрічкою в один рядок на 1 га шкілки висаджували 100 тис. щеп (варіанти 3.1, 3.2, 3.3, 3.4 та контроль 1.1, 2.1), при висаджуванні щеп винограду стрічкою у два рядки - 172 тис. щеп (варіанти $1.1,1.2,1.3,1.4,2.1,2.2,2.3,2.4$, контроль $1.2,2.2$ ).

Під час виконання роботи використовували польові, лабораторні та розрахунково-порівняльні методи. При аналізі економічної ефективності виробництва щеплених саджанців винограду визначали такі показники: врожайність культури (вихід стандартних саджанців із шкілки, шт./га), витрати на 1 га шкілки, в тому числі: вартість поливної води, електроенергії та вартість краплинної стрічки, собівартість саджанців, дохід від реалізації та рівень рентабельності.

Основні результати дослідження. На формування режиму краплинного зрошення виноградної шкілки в умовах півдня України впливали РПВґ, схеми висаджування щеп у шкілці та природні опади (рис. 1).

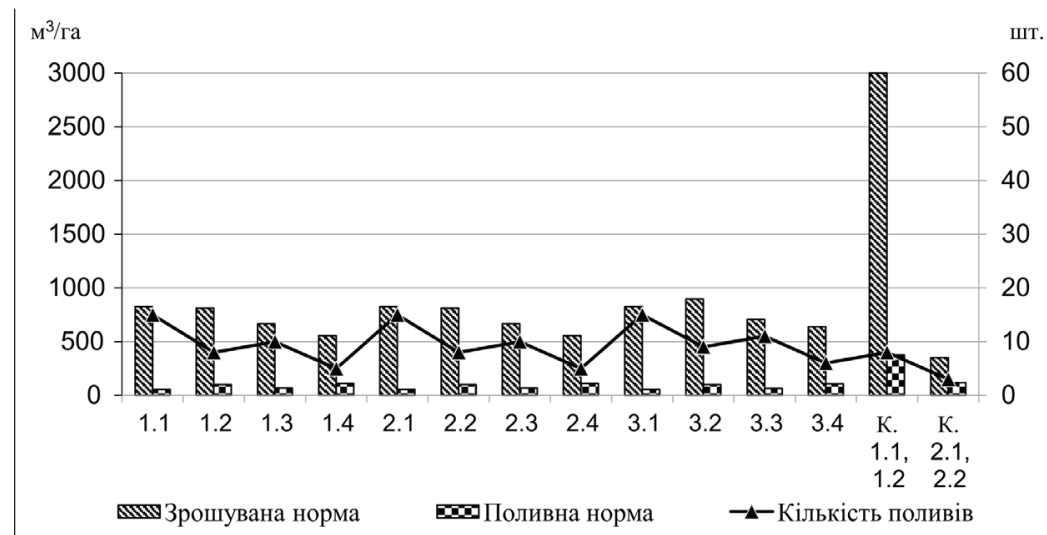

Рис. 1 - Режими краплинного зрочення виноградної икілки залежно від РПВГ, схем садіння щеп у шкілці, 2015-2017 pp.

Згідно з отриманими результатами доведено, що режим зрошення за підтримання РПВҐ виноградної шкілки у межах 100-90\% НВ забезпечувався проведенням (у середньому за три роки) 15 поливів із зрошуваною нормою 826,0 м³/га (включаючи різні схеми садіння щеп); режим зрошення за підтримання РПВҐ у межах 100-80\% НВ забезпечувався проведенням 8 поливів із зрошуваною нормою 813,0 м³/га при садінні щеп винограду у шкілці стрічкою у два рядки та 9 поливів із зрошуваною нормою 896,0 м³/га при садінні щеп винограду у шкілці стрічкою в один рядок; режим зрошення за підтримання РПВҐ у межах 100-90-80\% НВ забезпечувався проведенням 10 поливів із зрошуваною нормою 665,0 м³/га при садінні щеп винограду у шкілці стрічкою у два рядки та 11 поливів із зрошуваною нормою 707,7 м³/га при садінні щеп винограду у шкілці стрічкою в один рядок.
Для підтримання режиму зрошення за РПВґу межах 100-80-70\% НВ кількість поливів зменшувалась до 5 та 6, зрошувана норма - до 555,0 та 653,0 м³/га відповідно при садінні щеп винограду у шкілці стрічкою у два та один рядки. У контролі 1 проводили 8 поливів, зрошувана норма дорівнювала 3000 м³/га. У контролі 2 проводили

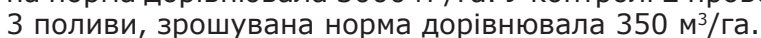

При вирощуванні щеплених саджанців винограду сорту Каберне Совіньйон у контролі 1.1 витрати на 1 га шкілки дорівнювали 247243,4 грн., найбільша частка 3 яких припадала на виконання робіт згідно технологічних карт та вартість матеріалів для щеплення - 211455,9 грн., у контролі 1.2 вони збільшувалися до 335343,4 грн. (за рахунок виконання робіт згідно технологічних карт на вирощування саджанців другого рядка стрічки) (рис. $2,3)$.

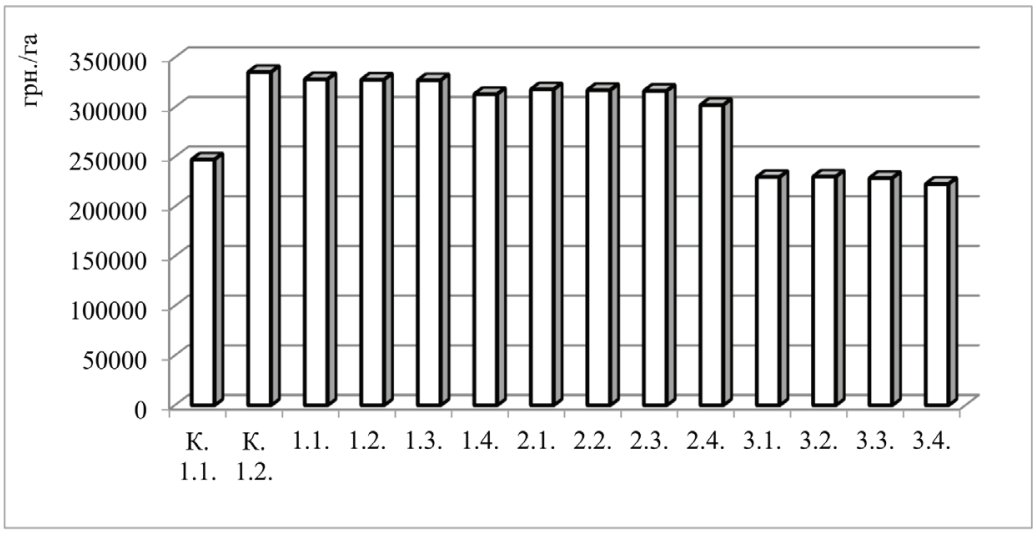

Рис.2 Витрати на вироцування 1 га виноградної иккілки (згідно технологічних карт), 2015-2017 pp. 


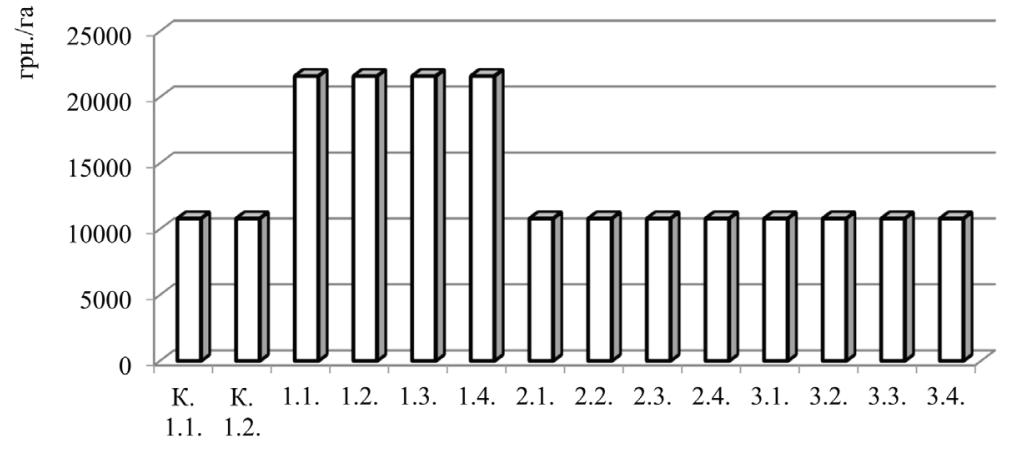

Рис.3 Вартість краплинної стрічки на 1 га виноградної икілки, 2015-2017 pp.

Витрати на електроенергію та вартість води у цих контролях були найбільшими, перевищуючи окремі дослідні варіанти на 236,3-623,4\% або в 3,4-7,2 рази (витрати на електроенергію) та 235,4-438,1\% або в 3,4-5,4 рази (вартість води) (рис. 4, 5). При виході стандартних саджанців із шкілки 51,7-52,0\% собівартість 1 тис. шт. саджанців дорівнювала - 3749,4 грн. (К 1.2) та 4778,6 грн. (К 1.1), рівень рентабельності відповідно - 305,6 та $216,8 \%$.

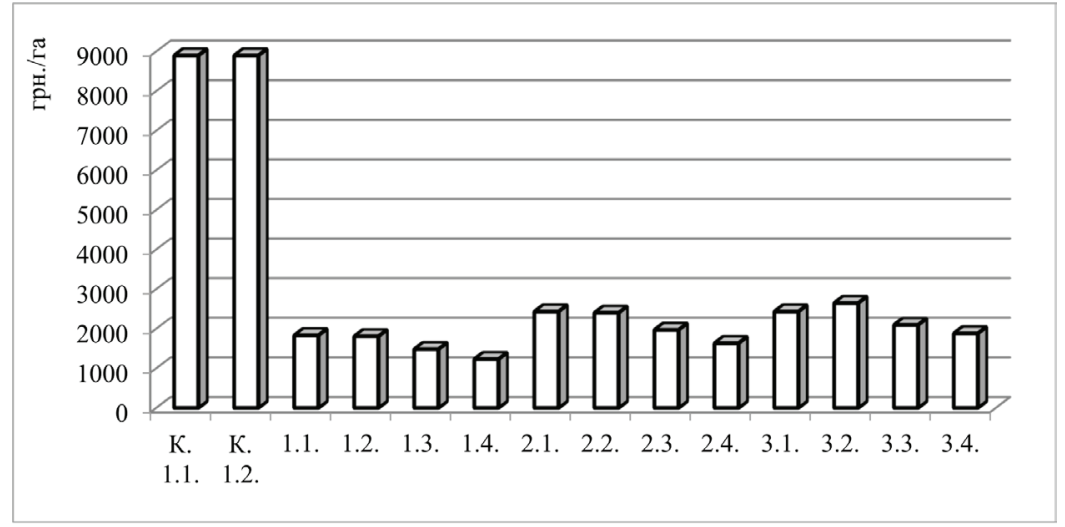

Рис.4 Вартість електроенерхї̈ за краплинного зрочення виноградної иккілки, 2015-2017 pp.

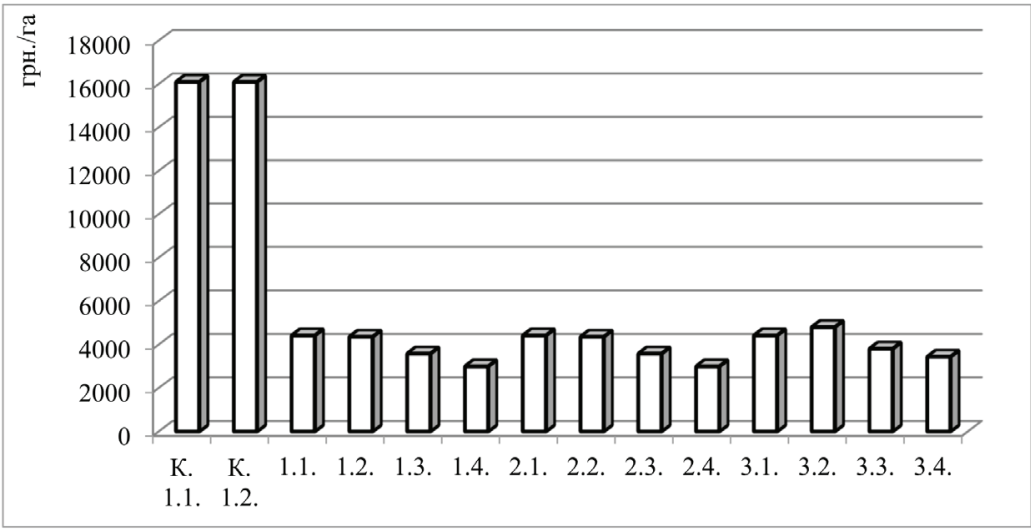

Рис.5 Вартість зрошуваної води за краплинного зрочения виноградної

\section{шкілки, 2015-2017 pp.}

У контролі 2.1 витрати на 1 га шкілки дорівнювали - 225171,1 грн., так само найбільша частка з яких припадала на виконання робіт згідно технологічних карт та вартість матеріалів для щеплення, у контролі 2.2 вони збільшувалися до 313271,1 грн. Але суттєво зменшувалися витрати на електроенергію та вартість води, оскільки щепи поливали тільки тричі за сезон в основні періоди їх розвитку. Порівняно з окремими дослідними варіантами, таке зменшення було на 15,7-60,8\% (витрати на електроенергію) та 37,2-60,9\% (вартість води). При виході стандартних саджанців із шкілки 21,7-22,2\% собівартість 1 тис. шт. саджанців дорівнювала - 9816,1 грн. (К. 2.2) та 10449,7 грн. (К. 2.1), рівень рентабельності відповідно - 55,1 та 45,9\%. Тому ці контрольні варіанти недоцільно розглядати з економічної та технологічної точки зору.

За підтримання вологості ґрунту виноградної шкілки на рівні $100-90 \%$ НВ, протягом усього періоду вегетації щеплених саджанців винограду Каберне Совіньйон та при формуванні стрічки з двох рядків загальні витрати на 1 га шкілки дорівнювали 328196,4 грн. (варіант 1.1), 317927,3 грн. (варіант 2.1). Збільшення витрат у варіанті 1.1 досягалось за рахунок збільшення вартості краплинної стрічки, порівняно з варіантом 2.1. При формуванні стрічки в один рядок загальні витрати на 1 га шкілки зменшувалися на 98533,6 грн. (варіант 3.1), 
в основному за рахунок зменшення вартості робіт згідно технологічних карт. У варіантах 1.1, 2.1 при виході щеплених саджанців винограду зі шкілки 54,3-54,5\%, середній їх вартості - 15,0 грн., собівартість 1 тис. шт. саджанців дорівнювала 3406,5-3503,0 грн., у варіанті 3.1 вона збільшувалась до 4186,6 грн., що пояснюється меншою кількістю щеп, висаджених на 1 га шкілки, та меншим виходом щеплених саджанців із шкілки (табл.1).

\begin{tabular}{|c|c|c|c|c|c|}
\hline \multirow[b]{2}{*}{ Варіанти досліду } & \multicolumn{5}{|c|}{ Показники } \\
\hline & $\begin{array}{c}\text { Вихід саджанців } \\
\text { з га, шт. }\end{array}$ & $\begin{array}{l}\text { Собівартість } 1 \\
\text { тис. саджанців, } \\
\text { грн. }\end{array}$ & $\begin{array}{c}\text { Ціна реалізації } \\
\text { саджанця, грн. }\end{array}$ & $\begin{array}{c}\text { Прибуток } 31 \text { га } \\
\text { шкілки, грн. }\end{array}$ & $\begin{array}{l}\text { у т.ч. додатко- } \\
\text { вий прибуток, } \\
\text { грн. }\end{array}$ \\
\hline К. 1.2 . & 89440,0 & 3749,4 & 15,0 & 1006256,6 & - \\
\hline 1.1. & 93740,0 & 3503,0 & 15,0 & 1077473,6 & 71217,0 \\
\hline 1.2. & 91446,0 & 3579,6 & 15,0 & 1044130,5 & 37873,8 \\
\hline 1.3. & 94256,0 & 3470,9 & 15,0 & 1086117,5 & 79860,9 \\
\hline 1.4. & 51886,0 & 6026,6 & 15,0 & 465281,1 & 0,0 \\
\hline 2.1. & 93453,0 & 3406,5 & 15,0 & 1082869,4 & 76612,7 \\
\hline 2.2 & 90586,0 & 3512,7 & 15,0 & 1040013,5 & 33756,9 \\
\hline 2.3. & 91848,0 & 3437,2 & 15,0 & 1062089,8 & 55833,2 \\
\hline 2.4 & 50338,0 & 6010,8 & 15,0 & 452496,4 & 0,0 \\
\hline
\end{tabular}

Додатковий прибуток з 1 га шкілки у варіантах $1.1,2.1$ складав 71217,0-76612,7 грн., у варіанті 3.1 64913,9 грн., рівень рентабельності - відповідно 335,5 (варіант 1.1), 346,7 (варіант 2.1) та 261,6\% (варіант 3.1) (рис. 6). Слід зазначити, що порівняно з контролем 1.2 у варіантах 1.1, 2.1 вартість електроенергії зменшувалась на 72,7-79,4\%, води - на 72,6\%;

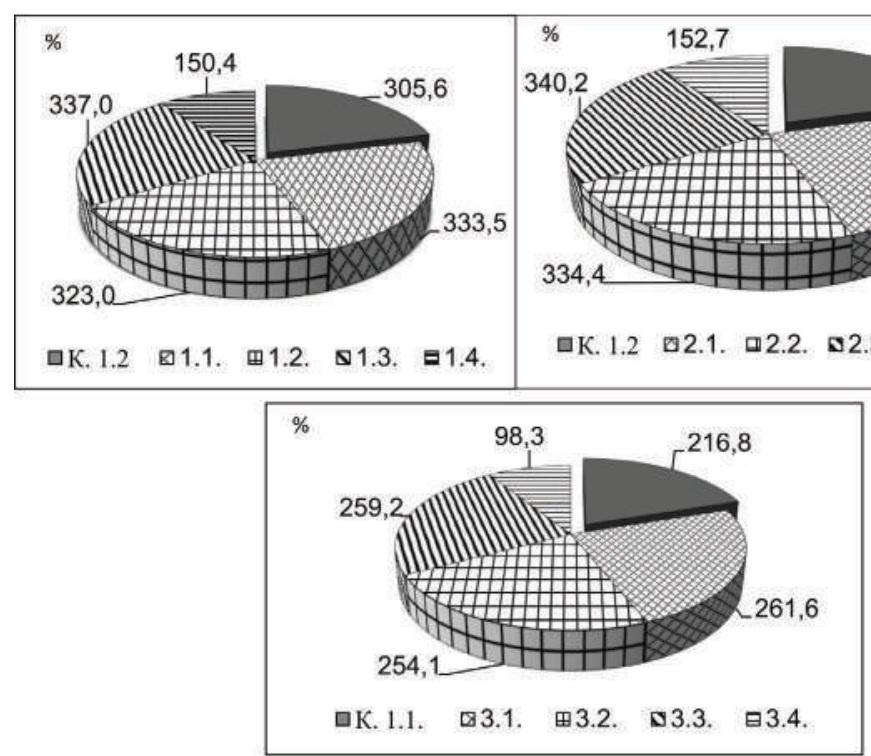

Рис.6 Рівень рентабельності режсимів краплинного зрочення виноградної шкілки по відношению до контролю 1, 2015-2017 рр.

порівняно з контролем 1.1 у варіантах 3.1 ці показники були меншими на $72,7 \%$.

За підтримання вологості ґрунту виноградної шкілки на рівні $100-80 \%$ HB, протягом усього періоду вегетації щеплених саджанців винограду сорту Каберне Совіньйон та при формуванні стрічки з двох рядків загальні витрати на 1 га шкілки дорівнювали 327712,9 грн. (варіант 1.2), 317209,8 грн. (варіант 2.2). При формуванні стрічки в один рядок загальні витрати на 1 га шкілки дорівнювали 230087,4 грн. (варіант 3.2). Незважаючи на те, що у варіанті 1.2 удвічі зменшувались витрати на електроенергію (порівняно з варіантом 2.2), збільшення витрат на 1 га шкілки відбувалось за рахунок монтажу двох краплинних стрічок у рядку. При середній вартості щеплених саджанців винограду - 15,0 грн., собівартість 1 тис. шт. саджанців у варіанті 1.2 дорівнювала 3579,6 грн., у варіанті 2.2 - 3512,7 грн., у варіанті 3.2 вона збільшувалась, у середньому на 720,9 грн. Додатковий прибуток був найбільшим у варіанті $3.2-49739,4$ грн., у варіантах 1.2 та 2.2 - відповідно 37873,8 та 33756,9 грн. Рівень рентабельності у цих варіантах дорівнював 323,0 (варіант 1.2), 334,4 (варіант 2.2), та 254,1\% (варіант 
3.2).

Порівняно $з$ контролем 1.2, вартість електроенергії зменшувалась на 73,0-80,0\%, води - на 73,0\%, порівняно 3 контролем 1.1, у варіантах 3.2 ці показники були меншими на $70,3 \%$.

За підтримання диференційованих РПВҐвиноградної шкілки - 100-90\% НВ у період укорінення щеп, до кінця періоду вегетації - 80\% НВ, витрати на 1 га шкілки, собівартість отриманої продукції, рівень рентабельності несуттєво відрізнялися від варіанту 100-90\% НВ. Це можна відмітити як для варіантів, де щепи висаджували в шкілці стрічкою у два рядки, так і для варіантів, де щепи висаджували в шкілці стрічкою в один рядок (табл. 2).

Економічна оцінка режимів краплинного зрошення виноградної шкілки залежно від РПВГ та садіння щеп у шкілці, 2015-2017 рр.

\begin{tabular}{|c|c|c|c|c|c|}
\hline \multirow{2}{*}{ Варіанти досліду } & \multicolumn{5}{|c|}{ Показники } \\
\cline { 2 - 6 } & $\begin{array}{c}\text { Вихід саджанців } \\
\text { з га, шт. }\end{array}$ & $\begin{array}{c}\text { Собівартість 1 } \\
\text { тис. саджанців, } \\
\text { грн. }\end{array}$ & $\begin{array}{c}\text { Ціна реалізації } \\
\text { саджанця, грн. }\end{array}$ & $\begin{array}{c}\text { Прибуток 3 1 га } \\
\text { шкілки, грн. }\end{array}$ & $\begin{array}{c}\text { у т.ч. додатко- } \\
\text { вий прибуток, } \\
\text { грн. }\end{array}$ \\
\hline к. 1.1. & 51666,0 & 4778,6 & 15,0 & 528089,9 & - \\
\hline 3.1. & 54833,0 & 4186,6 & 15,0 & 593003,8 & 64913,9 \\
\hline 3.2. & 53833,0 & 4267,1 & 15,0 & 577829,3 & 49739,4 \\
\hline 3.3. & 54166,0 & 4224,1 & 15,0 & 583512,8 & 55422,9 \\
\hline 3.4. & 29166,0 & 7647,9 & 15,0 & 214411,4 & 0,0 \\
\hline
\end{tabular}

Найменша рентабельність вирощування щеплених саджанців винограду була у дослідних варіантах за підтримання диференційованих РПВҐ шкілки - 100-80\% НB у період укорінення щеп, до кінця періоду вегетації 70\% НВ. У варіантах 1.4, 2.4, 3.4 витрати на 1 га шкілки були майже на рівні контролю 1. При середній вартості щеплених саджанців винограду - 15,0 грн., собівартість 1 тис. шт. саджанців у цих варіантах була майже вдвічі більшою порівняно з контролями та іншими дослідними варіантами. Додаткового прибутку варіантів 1.4, 2.4, 3.4 по відношенню до контролю 1 (К. 1.1, 1.2) відмічено не було, рівень рентабельності дорівнював 150,4, 152,7 та 98,3\% проти 261,2\% у контролі 1.

Протягом 2018-2019 рр. була проведена апробація найбільш ефективних режимів краплинного зрошення виноградної шкілки у ДП «ДГ «Таїровське». Застосовували такі режими краплинного зрошення: РПВГ - 100-90\% НВ, 100-90-80\% НВ, 100-80\% НВ. Отримані результати порівнювали з контрольними варіантами: контроль 1 - норма зрошення 3200 м2/га, контроль 2 норма зрошення 350 м3/га. Виноградну шкілку ДП «ДГ «Таїровське» розміщували на площі 1,2 га, щепи висаджували стрічкою у два рядки з монтажем однієї краплинної стрічки. Роботу проводили на щепах та саджанцях сортів Одеський чорний та Сухолиманський білий.

3 урахуванням витрат на вирощування щеплених саджанців винограду у господарстві встановлено, що порівняно з контролем 1:

за підтримання на виноградній шкілці РПВГ $100-90 \%$ НВ досягається економія поливної води на $64,0 \%$, електроенергії - на 65,0\%; рівень рентабельності дорівнював 280,0 \%;

за підтримання на виноградній шкілці РПВГ $100-80 \%$ НВ досягається економія поливної води на $70,0 \%$, електроенергії - на 72,0\%; рівень рентабельності дорівнював 240,0 \%;

- $\quad$ па підтримання на виноградній шкілці РПВГ 100-90-80\% НВ досягається економія поливної води на $68,0 \%$, електроенергії - на 71,0\%; рівень рентабельності дорівнював 275,5\%.

Висновки. Економічний ефект застосування краплинного зрошення на виноградній шкілці досягався за рахунок збільшення виходу стандартних саджанців із шкілки, економії поливної води, електроенергії, дотримання раціональних схем садіння щеп у шкілці. Найбільший рівень рентабельності вирощування щеплених саджанців винограду був у варіантах, де щепи висаджували в шкілці стрічкою у два рядки з монтажем однієї краплинної стрічки, а вологість ґрунту підтримували на рівні 100-80\% НВ та 100-90-80\% НВ. У цих варіантах він дорівнював $334,4 \%$ та 340,2\% при 305,6\% у контролі 1 . Вартість використаних енергетичних ресурсів та їх виробничі об'єми зменшувались, у середньому, на 72,0-78,0\%. Вказані режими краплинного зрошення виноградної шкілки рекомендовано для застосування у розсадницьких господарствах та розсадниководами-практиками.

\section{Література}

1. Зеленянська Н., Борун В. Економічна ефективність вирощування саджанців винограду за краплинного зрошення. Соціально-економічні проблеми аграрного розвитку регіонів : матеріали Всеукр. наук.-практ. конф., м. Житомир, 16 травня 2017 року. Житомир : ЖНАЕУ, 2017. С. $79-83$.

2. Кравчук А. О., Казанджі А. В. Проблеми та пріоритетні напрями розвитку виноградарськовиноробної галузі України. Держава та регіони. Серія : Економіка та підприємництво. 2019. № 2. С. 41-47.

3. Каламан О. Б. Основні проблеми ефективного управління підприємствами виноградарсько-виноробного підкомплексу. Економіка : реалії часу. 2015. № 4 (20). С. 239-243.

4. Цветанов Е., Куманов К. Подобряване поливния режим на лозово вкоренилище: модел на нарастването на активния почвен обем. Journal of Mountain Agriculture on the Balkans. 2011. Vol. 14, 5. P. 1099-1110.

5. Кириченко А. В., Дутова А. В., Белик Н. В. Тензиометрический способ определения влажности почвы при выращивании саженцев в виноградных школках. Научный журнал Российского НИИ проблем мелиорации. 2013. № 2 (10). С. 1-10.

6. Кружилин И. П., Курапина Н. В., Гусев Д. Э. Элементы технологии выращивания саженцев винограда при капельном орошении. Природообустройство. 2008. № 3. C. 25-28.

\section{References}

1. Zelenianska, N., Borun, V. (2017). Economic efficiency of growing grape seedlings under drip irrigation. Sotsialno-ekonomichni problemy ahrarnoho rozvytku rehioniv : materialy Vseukr. nauk.-prakt. konf., m. Zhytomyr, 16 travnia 2017 roku. Zhytomyr : ZhNAEU, 79-83. (in 
Ukrainian).

2. Kravchuk, A. O., Kazandzhi, A. V. (2019). Problems and priority directions of development of the viticulture and winemaking industry of Ukraine. Derzhava ta rehiony. Seriia : Ekonomika ta pidpryiemnytstvo. № 2, 41-47. (in Ukrainian).

3. Kalaman, O. B. (2015). The main problems of effective management of enterprises of viticulture and winemaking subcomplex. Ekonomika : realii chasu, № 4 (20), 239-243. (in Ukrainian).

4. Tsvetanov, E., Kumanov, K. (2011). Improving the regime of irrigation of vines: a model for increasing the active volume of the soil. Journal of Mountain Agriculture in the Balkans. Vol. 14, 5.P. 1099-1110. (in Bulgarian).

5. Kirichenko, A. V., Dutova, A. V., \& Belik, N. V. (2013) Tensiometric method for soil moisture determination during vine sapling growth. Nauchnyj zhurnal Rossijskogo NII problem melioracii, 2(10), 1-10. (in Russian).

6. Kruzhilin, I. P., Kurapina, N. V., \& Gusev, D. Je. (2008). Elements of technology for growing grape seedlings with drip irrigation. Prirodoobustrojstvo, 3, 25-28. (in Russian). 